\title{
Szymon Wierzbiński, $U$ boku bazyleusa. Frankowie $i$ Waregowie $w$ cesarstwie bizantyńskim $w$ XI w., Byzantina Lodziensia XXXVII, Wydawnictwo Uniwersytetu Łódzkiego, Łódź 2019, pp. 422
}

The presence of European mercenaries in Byzantium at the end of the Early Middle Ages is an intriguing subject, concerning a colourful group of warriors forming an intercultural link between the West, North and East Europe, and the Byzantine and Muslim world. However, this is not a new subject, as it has been undertaken repeatedly, starting from the studies of V.G. Vassilievsky from the early 1900s. At the same time, this subject has not been exhausted yet. The studies conducted so far to a large extent concern the mercenary service undertaken in the imperial army by the socalled Varangians, but even in this case there is a lack of comprehensive, modern and more widely available studies. At the same time the studies concerning the presence of not only the Varangians, but also the 'Franks' in the Byzantine army seem to be limited to a recent article by $\mathrm{G}$. Theotokis. Szymon Wierzbiński has therefore taken up the challenge of filling in this gap, trying to outline the image of activities, both of the West- and the North-European mercenaries in the Byzantine military structures. To a major extent, he has been successful in this challenge.

In the introduction (pp. 1-28) Sz. Wierzbiński outlines the previous state of research and presents an impressive spectrum of sources that form the basis of research analysis. He divides these sources into three groups: 'sources originating primarily from the Byzantine tradition', 'WestEuropean sources' and 'Scandinavian sources'. The researcher emphasises that in this latter group 'the most numerous are the texts which can be described by a collective term Íslendingasögur (Icelandic sagas)', but his use of the term is not entirely correct. Íslendingasogur are the so-called Sagas of Icelanders - a sub-genre of Icelandic sagas describing the stories of particular Icelandic families and regions, such as the ones listed in the book: Hallfreðar saga, Grettis saga and Laxdaela saga, but not Yngvars saga vífforla, recognised as a legendary saga (fornaldarsogur), or Knýtlinga saga, which belongs to kings' sagas (konungasogur). In the introduction Sz. Wierzbiński also summarises the problems related to the etymology of the words 'Rus' 
and 'Varangian'. In this latter case he indicates the meanings which used to be attributed to this term by various nations, recognising E.A. Melnikova's thesis as the most convincing. However, the scholar expresses his opinion in an annotation (14), without presenting broader reflections in the main text. Sz. Wierzbiński also quotes an observation of S. Vinci, drawing attention to Lombard king Rothari's edict of 643, in which the foreigners are described with a term 'waregang', and their legal status reminds of the status of Byzantine Varangian guardsmen. This interesting - especially for the understanding of the etymology of the word 'Varangian' - observation was not developed by the scholar in the main text, but limited to an annotation (15). Annotations, some of them fairly extensive, in which the author includes a lot of additional information, are a constant feature of the reviewed book.

In the first chapter (pp. 29-70) titled Spadkobiercy Imperium Romanum Sz. Wierzbiński describes the military organisation of Byzantium in its structural and administrative dimension, including the changes occurring in its functioning in the Early Middle Ages. The most important to the subject undertaken by Sz. Wierzbiński is the last part of the chapter concerning the ethnic origin of foreign warriors engaged in Byzantine military undertakings in the 10th century - which outlines a colourful background for the further investigating. The author is correct in taking note that not all the foreign warriors supporting the activities of the emperor did so in accordance with contractual terms, hence he introduces their division into 'mercenaries' and 'allies'. What draws particular attention is the scholar's broad command of secondary literature - this impression is also maintained in the course of reading of the following chapters.

The second chapter (pp. 71-86), Nowe wyzwania, stare zagrożenia, starts with a smooth transition to the origins of the Varangian Guard. Sz. Wierzbiński associates them with the guard created from the Rus' warriors by Basil II in response to the internal problems the emperor had to deal with, and as a result of an agreement he concluded with the Rus' prince Vladimir the Great in these not-too fortunate conditions. The circumstances contributing to the development of the Varangian contingent perceived by Sz. Wierzbiński also include the offensive politics of the Byzantine rulers conducted from the mid-10th century. Implementation of this politics increasingly depended on the forces of constant nature in army structures, in the form of professional soldiers and mercenaries. At the same time, the author describes the geopolitical situation of Byzantium, outlining the political context of the leading theme of the book.

The main issues undertaken by the work are expressed more strongly with chapter three (pp. 87-126), Drogi do Bizancjum. Nowe obszary zaciagu. 
In its initial part the author outlines the Byzantine-Rus' relations, which in the period of cooperation between Basil II and Vladimir the Great had particular influence on the reinforcement of presence of the Varangian/ Rus' warriors in the structures of the imperial army, being also significant in the period of rule of Yaroslav the Wise. The author also draws attention to the figure of the mysterious Chrysocheir - 'Goldhand' - trying to join the Varangian Guard, who is presented by John Skylitzes as a cousin of a Rus' prince. Sz. Wierzbiński agrees with the thesis on Scandinavian origin of the mentioned daredevil, seeing the source of the proper noun Chrysocheir in a possible Scandinavian nickname Gullhendi, which, according to the author, could have referred to generosity of the commander with regard to the warriors. At the same time, however, the scholar erroneously recognises the term kenning as a nickname (also in the following chapter on page 199 - annotation 395). Kenning is not a nickname, but a compositional element of metaphorical nature characteristic of skaldic poems, created in reference to various aspects of life. One has to admit that the observation concerning Chrysocheir (enclosed in an annotation, which is then repeated at the end of the book - p. 334) is very interesting, and the reference to the content staying behind the mentioned nickname can be sought in the kennigs of certain skald verses, such as gollsendir - 'gold-distributor' (Einarr skálaglamm Helgason, Vellekla, stanza 36), gollvorpuðr - 'one who throws gold' (Glúmr Geirason, Gráfeldardrápa, stanza 4), gollskýflir 'gold-destroyer' (Guthormr sindri, Hákonardrápa, stanza 4), or gollkennir - 'gold-master' (Pórðr Kolbeinsson, Eiríksdrápa, stanza 14). The scholar is also correct to note that refusal to accept Chrysocheir and his people to service to the emperor could have been related to a change in the political circumstances as a result of Anna Porphyrogenita's death.

Sz. Wierzbiński then moves on to the issue of relations between the empire and Scandinavia, and addresses the issues related to the political situation in the North at the end of the Early Middle Ages. He emphasises that for a major part of the rule of King Olaf Skötkonung Sweden was under Danish influence, adding in an annotation (30) that 'with regard to territory this was to the benefit of the kingdom. This refers to the territorial acquisitions awarded to the Swedes by Denmark after the defeat of Olaf'. The reader could be under the impression that the defeated Olaf was the mentioned Skötkonung, but this actually refers to a Norwegian ruler Olaf Tryggvason and his defeat in the so-called Battle of Svolder (1000) - besides, on one of the following pages the author proves his knowledge on the subject of these events. According to the later tradition, Olaf Skötkonung gained as a result the lands in eastern Norway. However, it should be noted that in consequence of the battle the position of Denmark with regard to 
allies seems to have been strengthened, and the new regions were enjoyed by the Swedes only for some time, as the influences of the Norwegian rule were restored there by Olaf Haraldsson (the Saint).

When mentioning at page 97 the Danish attempts to seize power in England, the author accidentally confuses the actions of Sweyn Forkbeard with the actions of Cnut the Great, whereas in turn he makes an error 'entrusting' the latter's command of the invasion of 1015 to his brother Harald. On the following page, when discussing the childhood spent in Rus', he confuses Olaf Haraldsson with Olaf Tryggvason. Moreover, the former later stayed in Normandy for a fairly short time, not for several years - as stated by the author on page 101 - and in addition he seems to be seeking support in missionary activities primarily from the English, not Norman, clergy. The author also adds that Olaf Haraldsson died in the Battle of Stiklestad at the hand of Pórir hundr. Actually, however, we do not have certain information concerning the direct circumstances of the future saint's death. Olaf Haraldsson's skald, Sigvatr Pórðarson, makes a suggestion that Pórir hundr dealt a blow to the former king, without mentioning that it was mortal, and the later tradition in turn attributes the deadly blows dealt to Olaf not only to Pórir. This state of affairs seems to be reflected in the words of Theodoric the Monk, who states that he does not want to write how many times Olaf was wounded or who dealt the mortal blow, as there are different versions on this subject. One more erroneous information is related to the power in Norway, wielded - according to the author - 'directly' by Cnut in the years 1030-1035.

At the same time, Sz. Wierzbiński lists a range of political factors - such as the Danish conquest of England - which seem to make travels of larger groups of the Danes to Byzantium (in the first half of the 11th century) unlikely. However, one should make a note of good relations between Denmark and Rus' manifested in the marriage of the sister of Cnut the Great and the son of Yaroslav the Wise, as well as the English coins (paid to the Danes as a part of tribute) found in Rus' - to a large extent minted in the earlier period of Cnut's rule in England (1017-1023). Most of them were found in Novgorod and in adjacent areas. This allows one to assume that at least Garðariki was to some extent in the area of interests of the Danes in the period of rule of Sweyn Forkbeard's son.

In the further parts of the chapter the scholar outlines the history of formation of the Scandinavian/Norman dominion in Normandy, and then presents the socio-political changes in the British Isles in the period from the 9th to the 11th centuries, simultaneously determining the environment from which English mercenaries - who came to Byzantium after 1066 originated. 
In chapter four (pp. 127-206), Barbarzyńcy z Ultima Thule, Sz. Wierzbiński fully moves on to the main theme of the book, discussing engagement of Scandinavian/Rus' and English/Anglo-Dane warriors in the Byzantine forces. Dealing with both mercenary groups in a single chapter is by all means justified due to their intertwined history within the framework of the Varangian Guard. The author bases his reflections not only on the previous findings of the researchers, but also on the analysis of sources that are - which deserves recognition - characterised by very different provenance. In the discussion of the problem Sz. Wierzbiński introduces a certain temporal caesura, referring to the period before the arrival of Harald Hardrada to Byzantium (the most colourful of the Varangians described in the kings' sagas), the period of Harald's activity, which manifested in renewed dominance of the Scandinavians over the Rus' warriors in the composition of the Varangian Guard, and the period after Harald left Byzantium, when the dominance of the Rus' warriors was renewed. One can feel a certain insufficiency, however, due to the limited focus on this figure (i.e. Harald Hardrada), especially since he is outlined quite broadly in the sources and draws interest of the scholars, whose opinions are worthy of somewhat more in-depth synthetic discussion. When it comes to the Old Norse sources which are referred to by the author, a lack of appropriate handling can be sensed in terms of methodology.

Warriors from the North do not seem, however, to constitute such a brisk group of mercenaries - able to pursue their own political goals and founding influential families - as for example the Normans, whose activities are outlined by Sz. Wierzbiński in chapter five (pp. 206269), Normanowie $i$ 'inni Frankowie'. This part of the work is dedicated by the author to the presence of not only the mentioned Normans in the military structures of Byzantium, but the 'Franks' in general, who according to Sz. Wierzbiński also include soldiers originating from other areas of contemporary France. Since they partially held a different position in these structures than the Varangian/Rus' warriors and they were perceived in a specific way by the Byzantines, raising their issue in a separate chapter is justified. The scholar outlines the specificity of the Franks in an interesting way - differentiating those who decided to go to Byzantium from those who sought their luck, at least initially, in Southern Italy and at the Iberian Peninsula - and based on exhaustive source analysis describes their role in particular external and internal conflicts that took place in the territories ranging from Sicily to the Middle East border region of Byzantium. Therefore, the author positions the discussed issue in a broad context of the turbulent political history 
of the empire, seeing in the Frankish mercenaries not only an element of support in Byzantine military challenges, but also the source of threats, which is proved by the anti-imperial activities of Hervé Frankopoulos, Robert Crispin and Roussel de Bailleul.

In the case of both Frankish and Varangian mercenaries the main factor drawing them to Byzantium was the prospect of becoming rich and raising their own status. This is why the author dedicates the next chapter of the book (pp. 271-320), Bogactwo, stawa i cześć, to the issues related to the monetary system of Byzantium, the earnings of soldiers, the structure of the Byzantine court, simultaneously outlining examples of careers of the enlisted Franks and Varangians. At the same time, the author notes that in the case of Varangian-Rus' warriors it is more difficult to find information on promotions than in the case of the Franks. The greatest problem is caused by their exiguous presence in Byzantine texts. In reference to the listed examples of mercenaries from the North the scholar is right to use the word 'characters' - since it remains an enigma to what extent the described Varangians are a product of literary conventions and images typical of sagas formed by generations. On the other hand, the term 'author' should be used with slightly greater caution in reference to the persons writing down the sagas - these are to a large extent products of oral-literary transmission which has been continued for centuries in some cases.

Since the Franks and Varangians comprised the same type of military forces and at times they were engaged in joint military operations, Sz. Wierzbiński devotes a part of the last chapter - (pp. 321-346), Zdrade maja we krwi? - to their mutual (and internal) relations. The scholar discusses, among other things, the revolt of the Normans during a Sicilian campaign and participation of Varangians in these events, and referring to a verse of Pjóðólf Arnórsson he notes that Harald Hardrada 'also served in Langbarda'. To be specific, however, the skald refers to the future king entering á landi Langbarda ('onto the land of the Lombards). Within the framework of this chapter the author also ponders on the image of Varangian and Frankish mercenaries in the eyes of Byzantine elites. From this image emerge two opposing features, i.e. loyalty of the former and the later perfidy of the latter, as well as two shared features - military capabilities and valour. In this way the author smoothly heads towards the conclusions, presented in a separate, final part of the work.

The problem undertaken by Sz. Wierzbiński is ambitious, partially exceeding the natural area of interest of Byzantinologists. Certain lapses on the Scandinavian matters by no means diminish the competences of the scholar with regard to Byzantine studies and bear no influence on 
the main research course of the work. The author's courage deserves recognition - he did not hesitate to use a broad spectrum of sources, making accurate observations. An innovative work has been created as a result, especially in the area of Polish historiography, and definitely one worth reading.

Maciej Lubik

(University of Zielona Góra)

https://orcid.org/0000-0002-5893-4995 